\title{
Research on the Students' Rights Guarantee in the Management of Colleges and Universities
}

\author{
Fengyun Wei \\ Party School of the ShanDong Committee of the CPC, Jinan, Shandong, \\ 250103, China
}

\begin{abstract}
With the implementation of the strategy of administering the country according to law, the construction of legal system has been perfected, and people pay more and more attention to their legal rights. With the development and perfection of the socialist market economy in our country, the relationship between universities and college students is gradually changing from traditional special administrative relations to educational contractual relations. Guarantee the right of college students has become a symbol of modern management of colleges and universities.
\end{abstract}

Keywords: students' rights guarantee, management, colleges and universities

\section{Introduction}

With the progress of the rule of law and the awareness of civil rights, college students, as a special group in society, have begun to pay more attention to the protection and realization of their rights. In recent years, in the conflict between the management rights of university students and the rights of students, due to the university students' management power is too strong, the power of college and students' rights imbalance, resulting in many students' rights have been violated, The litigation cases of the dock, aroused widespread concern in society, but also led to more college students' claims. This phenomenon on the one hand reflects the "rule of law" today, people's rights awareness has been generally improved, more and more people, including college students struggle for the rights, on the 
other hand also reflects the current university in China. There are some unavoidable and urgent problems in the process of management. At the same time, it also exposes the problem that the mechanism of the protection of students' rights in higher education is not perfect.

In view of the present legislation of higher education in China, the nature of the legal relationship of higher education is fuzzy and uncertain, and the basic rights of the students 'vital interests are seriously lacking. The students' objectification and weak tendency of college students are obvious, and more prominent college students have been formed. Rights issue. In this situation, adhere to the concept and the specific system to student rights-based, full respect and protection of the legitimate rights of students is to comply with the development of the times and the inevitable requirement of progress of the rule of law. The connotation of the rights of students in colleges and universities Students in colleges and universities are both citizens and educated dual identity groups. The rights of students in universities can be regarded as the ability or qualification of the acts or omissions of the students in the process of education stipulated by the law or the acts or omissions of others, that is, the students can decide to do something of the licensing and security means. A person's rights are closely related to his or her status and legal status. People of different status and legal status have different rights. College students have dual identities: first, they are citizens of the state; and second, they are citizens of higher education at school. The legal status of students is different and the subject qualification obtained is also different. College students, as educated citizens, enjoy all the rights of citizens, such as personality rights and identity rights, in the legal relations with teachers, schools and educational administrative organs when participating in educational activities. At the same time, as an educated, college students enjoy the equal rights of education, fair evaluation, material assistance and so on. In the case of student status, they enjoy both general legal rights as citizens and special legal rights as educators.

\section{The background of college students' rights protection}

\subsection{The inherent requirements of the rule of law in university management}

In recent years, with the deepening of the rule of law, people's awareness of the rule of law and awareness of rights and interests have been increasing, and the awareness of college students' rights has also been significantly enhanced. Although the increase in the number of students in colleges and universities has some negative impact on some colleges and universities, but from another point of view, this is a great progress, reflecting the concept of rights and the rule of law is in-depth higher education management. At the same time, the legal framework to protect the rights of college students has been basically formed. Over the past decade, China has promulgated a series of laws and regulations on education, to promote the development of Chinese education, safeguard the national management principles of education, the protection of citizens' right to 
education, adjustment of educational activities in various social relations, The legal protection. Secondly, the university management model is also gradually changing. Nowadays, the management mode of students in colleges and universities is changed from traditional management to management and service. Generally, students 'satisfaction is taken as the standard of work and more attention is paid to students' development. All these have laid the indispensable institutional foundation for the guarantee of the rights of college students, which is of great significance to promote the rule of law and guarantee the rights of college students.

\subsection{The inevitable requirements to build a harmonious campus}

In recent years, China has already begun to protect the rights of college students through legal means. It can be said that the rights of students in colleges and universities have been paid attention to, but there are still some problems from the social and educational practice. Schools are specialized educational institutions, is the place to train personnel; teachers are human soul engineer, is the guide to the growth of students. Schools and teachers shoulder the responsibility to protect the interests of students, promote the healthy growth of students. However, due to thousands of years of deep-rooted ethics under the influence of the formation of the obligation-centred way of thinking long-term imprisonment of people's minds, our school is still relatively scarce, the school students as the main body of the lack of substantive identity, some schools even exist serious violations of the legitimate rights and interests of students phenomenon. There have occurred in the campus of the violations of the legitimate rights and interests of students have occurred to schools and teachers for the defendant of the increasing number of infringement proceedings.

At present, there are still many abnormal phenomena such as insulting students' personality, infringing students' right to privacy, reputation, education right, health right and property right, which bring many obstacles to the realization of students' rights in our colleges and universities. It can be said to clear these practical obstacles to building a harmonious campus has become an inevitable requirement.

\section{The value analysis of the college students' rights protection}

\subsection{It is conducive to the healthy development of college students}

The main body consciousness and the subject ability of university students not only constitute the intrinsic foundation of students 'comprehensive development, but also the performance of the highest level of students' personality development. In the long-term practice of education management, colleges and universities are accustomed to regard students as passive educational management bearers, often simplifying the students in the pre-set "educational goal system" and "rules and regulations" to shape and management. (1) to protect the rights of college students, 
so that they get the right to defend their legitimate rights and interests of the main body capacity to calmly into the rights of the main body complex society, can effectively crack the educational managers and students between the "command obey "One-way relationship, help students in their own rich exercise of the exercise of the gradual formation of subject consciousness and the development of the main ability to learn with a rational look at their own legitimate rights and interests of university management behaviour and illegal or improper Education and management behaviour questioned and criticized, so that the free and full development of students to become interrelated, dialectical unity of the whole. Therefore, only under the framework of the rule of law, college students can achieve equal development, harmonious development and free development, not only the students need vitality, ability, personality can be fully developed, but also enable students to social relations can also be harmonious development, including The harmonious development between college administrators and students, the development of students 'individual and group, and so on, so as to promote the development of universities and students' free and comprehensive healthy development into a unified whole.

\subsection{It is conducive to the rule of law in student management}

Student management refers to the school or the educational administrative department within the scope of legal authority, in accordance with the corresponding procedures, the implementation of educational management functions, the organization of students, regulate and regulate the behaviour. Student management is the key to education. From the implementation of the management of the main body of the division, student management is divided into two parts: First, the state and its educational administration departments, through the development of laws, regulations, regulations, student management to make the appropriate provisions. So that students can manage the law. Second, the school in accordance with the provisions of laws and regulations, to develop the school's student management system so that the provisions of laws and regulations of specific, standardized and institutionalized. With the improvement of college student rights protection mechanism, we can better realize the rule of law in student management.

\subsection{It is conducive to the modernization of Chinese education legal system}

The rule of law society is through a series of good law operation to establish a stable and good social order, through the grant and control of public rights to achieve the protection of human rights and freedom of citizens, to achieve social fairness and justice. Among them, the educational legal system is the activities and processes of legislation, educational administration, law enforcement and judicial supervision. The modernization of the rule of law is a process of historical creative change from the traditional man-governed society to the modern one. It is a transition from the value-regulating system to the rule-based system. From the perspective of the developmental stages of Chinese educational 
law transition, the protection of students' rights is also in the process of continuous development.

\section{The mechanism construction of college students' rights protection}

\subsection{Cultivate the rights awareness of the students and students self- organization security mechanism}

To further strengthen the awareness of self-protection of university students to improve their self-protection ability. We should actively carry out educational activities to guide students to gradually establish the correct awareness of the subject and rights, from passive to active, consciously enhance the legal concept. Especially to create a good atmosphere of awareness of the rights of the right to strengthen the teaching of law and law students in the practice of law education, through the advocates of student rights, can effectively protect the rights of college students to achieve, which is an important part of legal education. Students' rights should be strengthened to ensure the support of the students. On the one hand, students should not be alienated from students. On the other hand, they should be combined with resources such as enlightened professors, media and student representatives to form a collective operation.

\subsection{Improve the education laws and regulations, form a comprehensive legal security system}

On the one hand, because of the complexity of the students 'problems, the definition of college students' rights is only described in the phenomenon. On the other hand, due to the delay in the legislation of college students 'rights, the students' rights have not been paid much attention. It can be said that the legislative protection is the first prerequisite to protect the rights of college students. Legislative protection refers to the protection of the rights of college students by improving the legal provisions. Therefore, we must further establish a comprehensive system of higher education laws and regulations.

\subsection{Establish the rule of law, build the rule of law university management system}

The realization of the rights of students in colleges and universities is closely related to their own educational level and the exercise of administrative authority. Colleges and universities as a place for students to enjoy the rights of the students have the right to direct protection obligations. Therefore, to effectively protect the rights of students, we must implement the principle of running a school according to the law and realize the rule of law in university management. 


\section{Conclusion}

In the management of college students, rights and obligations are the core contents of law. For university administrators, the development of student management mechanism needs to abandon the traditional concept of obligationbased management and effectively protect the legitimate rights of students. At the same time, promote the rule of law of students management, promote management according to law. However, in student management, it needs to focus on the concept of scientific management, not blindly meet, accommodate students' unreasonable demands.

\section{References}

[1] Wang Yaqin, Ren Ruiping. Citizen's Right to Education and Constitutional Relief, Applicable Law, 55(12), pp.68-70, 2011

[2] Wang Jun. Special power relations and the legal protection of the right to education in colleges and universities, Higher Education Exploration, 8(5), pp.8791, 2013

[3] Zhang Yongsheng. Research on the Rights of College Students. Legal System and Society 12(10), pp. 18-20, 2012

[4] Zhu Jun, Xie Fang. Analysis on the Judicial Guarantee of American College Students' Rights. Journal of Liaoning Administration College, 9(6), pp.58- 61, 2011

[5] Chen Jianguo. Adhering to the Scientific Development View and Guiding the Management of Universities. China Higher Education, 8(4), pp.85-87, 2014 